\title{
Dampak Liberalisasi Perdagangan terhadap Perilaku Pembentukan Harga Produk Industri melalui Structure-Conduct Performance Model
}

\author{
Siti Astiyah, Akhis R. Hutabarat, \\ Desthy V.B. Sianipar ${ }^{1}$
}

\begin{abstract}
This paper analyzes the impact of trade liberalization on the domestic price of industry product by utilizing the structure-conduct-performance (SCP) model. Applying the model to a pooled data of the 3 digits ISIC level of Indonesian industry product, the result shows the abnormal price determination on industry level after the increase of trade liberalization. The existence of this phenomenon, the downward profit-margin rigidity, is indicated by the increase of the profit margin, which reduces the social welfare and tends to persist the inflation. A clear consequence for the Indonesian Central Bank, is to faster and increase the credibility of the middle and long term inflation target, either by clarify the policy signal and its consistency and increase the cooperation with the government.
\end{abstract}

JEL: E31, L11, O24, P23

Keyword: Trade liberalization, Structure-Conduct-Performance, Price, Industry

1 Penulis adalah peneliti pada Direktorat Riset Ekonomi dan Kebijakan Moneter, Bank Indonesia. Kontak : astiyah@bi.go.id, akhis@bi.go.id, desthy@bi.go.id. 


\section{PENDAHULUAN}

\section{I.1 Latar Belakang}

Kebijakan liberalisasi (deregulasi) perdagangan telah dilakukan pemerintah sejak awal 1980an. Secara gradual pemerintah membuka perekonomian dengan mengeluarkan serangkaian kebijakan penurunan tarif dan menghilangkan kebijakan non-tarif yang menghambat masuknya barang impor secara bertahap. Di samping itu, Indonesia juga melakukan kerjasama perdagangan regional melalui ASEAN Free Trade Area (AFTA). Selanjutnya kebijakan liberalisasi perdagangan makin meningkat sejalan dengan derasnya arus globalisasi dan masuknya Indonesia dalam kerjasama internasional melalui World Trade Organization (WTO). Sementara itu, krisis nilai tukar yang berlanjut menjadi krisis finansial pada 1997 "membuka" kebijakan perdagangan yang harus sejalan dengan komitmen yang tertuang dalam Letter of Intent (Lol) antara pemerintah Indonesia dengan IMF sebagai bagian dari "IMF conditionalities". Ada beberapa hal yang belum menjadi komitmen Indonesia dalam WTO yang harus dilaksanakan sesuai dengan Lol tersebut.

Keuntungan yang sering dijadikan argumen dalam melakukan kebijakan liberalisasi perdagangan antara lain untuk meningkatkan efisiensi. Peningkatan efisiensi tersebut dilakukan melalui beberapa jalur berikut. Pertama, melalui peningkatan produktivitas karena makin efisiennya alokasi sumber daya baik dalam suatu industri maupun antar industri. Kedua, melalui peningkatan persaingan. Liberalisasi berpotensi untuk meningkatkan kompetisi antara produsen domestik dengan luar negeri, sehingga produsen domestik yang tidak efisien akan keluar dari industri selanjutnya industri secara keseluruhan akan menjadi lebih efisien. Disamping itu, dengan makin efisien dan makin meningkatnya tingkat persaingan suatu industri maka akan mendorong penurunan excess profit (marjin keuntungan yang "berlebih") menjadi normal profit pada produsen domestik yang sebelumnya menikmati "proteksi" dalam sistem pasar yang oligopolistik. Hal ini akan mendorong harga barang domestik dan impor menjadi relatif lebih rendah dan selanjutnya akan berpengaruh terhadap tingkat inflasi.

Pengendalian inflasi merupakan tugas pokok Bank Indonesia. Sejalan dengan hal tersebut, studi mengenai dampak kebijakan liberalisasi perdagangan terhadap pembentukan harga produk industri dipandang perlu. Hal ini dapat meningkatkan kemampuan memprediksi secara akurat tingkat inflasi dari sektor industri dan selanjutnya dapat meningkatkan akurasi prediksi inflasi indeks harga konsumen (IHK).

\section{I.2 Tujuan}

Penelitian ini bertujuan menganalisa dampak kebijakan liberalisasi perdagangan terhadap pembentukan harga barang industri di pasar domestik melalui pendekatan structure-conduct 
performance (SCP) model. Penggunaan SCP karena terkait dengan keterbatasan data yang tersedia. Pendekatan SCP pada dasarnya menganalisa dampak peningkatan perdagangan luar negeri terhadap kinerja perusahaan yang direfleksikan dalam price-cost margin (PCM) yang merupakan ukuran tingkat profitabilitas.

Dengan makin meningkatnya tingkat persaingan akibat makin terbukanya perekonomian, dihipotesakan bahwa perusahaaan tidak lagi dapat menikmati "excess profit" sehingga perusahaan akan menurunkan tingkat profitabilitasnya menjadi normal profit dan pada gilirannya akan menurunkan tingkat harga produk industri di pasar domestik.

\section{I.3 Metodologi}

Untuk menganalisa tujuan tersebut, studi ini menggunakan analisa kuantitatif dengan menggunakan pendekatan ekonometri dengan data panel (pooled time series, cross-section data) produk industri 3 digit ISIC level. Analisa regresi data panel yang diterapkan adalah regresi tertimbang lintas kelompok (cross-section weighted regression).

Mengingat peningkatan perdagangan internasional, khususnya impor, tidak seluruhnya merupakan kontribusi kebijakan liberalisasi perdagangan, maka hasil penelitian mengenai hubungan antara kebijakan liberalisasi perdagangan dengan profitabilitas industri domestik pada dasarnya lebih bersifat indikatif.

\section{PERKEMBANGAN KEBIJAKAN PERDAGANGAN LUAR NEGERI INDONESIA}

Kebijakan perdagangan Indonesia pada awalnya sangat protektif tetapi sejalan dengan perkembangan ekonomi dan tuntutan ekonomi global, ekonomi Indonesia makin terbuka. Regulasi perdagangan mulai dikurangi secara bertahap sejak 1980-an dan untuk meningkatkan perdagangan antara anggota ASEAN maka disepakati pembentukan AFTA yang pemberlakuannya secara bertahap dan berlaku penuh pada awal 2002. Kebijakan liberalisasi perdagangan Indonesia makin berlanjut terutama setelah krisis finansial 1997/98 sebagai konsekuensi dari komitmen pemerintah terhadap IMF.

\section{II.1. Perkembangan Kebijakan Perdagangan Luar Negeri}

Pada awal 1970-an, kebijakan perdagangan luar negeri bersifat protektif yang antara lain melalui pengenaan tarif tinggi bagi barang-barang impor sejenis yang diproduksi oleh perusahaan domestik. Untuk kebijakan perdagangan dalam negeri, pemerintah mulai 
memberikan hak monopoli bagi pelaku usaha tertentu. Pada awal 1980-an regulasi perdagangan luar negeri mulai dikendorkan secara perlahan dengan menurunkan tarif terutama untuk bahan baku bagi industri yang berorientasi ekspor.

Serangkaian kebijakan dikeluarkan pemerintah untuk menderegulasi perdagangan luar negeri secara bertahap, seperti tertera di Boks berikut ini:

\section{Boks : Rangkaian Kebijakan Deregulasi Perdagangan Indonesia}

\section{Paket Kebijakan 16 Januari 1982}

1. Mengatur ekspor/impor dan lalu lintas devisa untuk memperkuat daya saing ekspor Indonesia

2. Mengeluarkan kebijakan Imbal Beli (counter purchase)

\section{Paket Kebijakan 6 Mei $1986^{2}$}

1. Meningkatkan daya saing ekspor Indonesia dan mengurangi hambatan yang menyebabkan kurangnya minat investor

2. Kebijakannya meliputi kemudahan tataniaga ekspor non migas, fasilitas pengembalian bea masuk, fasilitas pembebasan bea masuk, dan pemberlakuan kawasan berikat

\section{Paket Kebijakan 25 Oktober 1986}

Menurunkan biaya produksi dengan menurunkan bea masuk sejumlah komoditi, perlindungan produksi dalam negeri melalui sistem tarif, pemberian fasilitas swap yang baru, dan kebijakan penanaman modal.

\section{Paket Kebijakan 15 Januari 1987}

Meningkatkan kelancaran penyediaan barang keperluan produksi dan perlindungan industri dalam negeri secara lebih efisien dengan mengubah kebijakan non-tarif menjadi tarif untuk sejumlah komoditas tertentu

\section{Paket Kebijakan 24 Desember 1987}

Dibukanya mobilisasi dana pada pasar uang, untuk memperlancar perijinan di bidang produksi, jasa dan investasi pada umumnya, serta untuk memperlancar arus ekspor dan impor

\section{Paket Kebijakan 28 Mei 1990}

Penetapan penggantian proteksi melalui tata niaga impor menjadi proteksi melalui tarif bea masuk yang ditujukan untuk meningkatkan dan memperkuat daya saing produk industri nasional

\section{Paket Kebijakan 6 Juli 1992}

Pemerintah melonggarkan tata niaga impor dan inti kebijakan sehingga setiap produsen bisa melakukan impor langsung tanpa memerlukan lagi rekomendasi dari Departemen Perindustrian

\section{Paket Kebijakan 10 Juni 1993 dan Paket Kebijakan dan Debirokratisasi 23 Oktober 1993}

Mencakup deregulasi di bidang otomotif, bidang ekspor/impor, bidang penanaman modal dan perijinan usaha, dan bidang farmasi

2 Untuk memperkuat dampak dari kebijakan ini, pemerintah kembali mendevaluasi nilai tukar rupiah terhadap dolar AS pada 12 September 1986. Selain alasan untuk meningkatkan ekspor, kebijakan juga dilakukan untuk mengurangi defisit anggaran pemerintah akibat jatuhnya harga minyak bumi. 
Disamping itu, dengan masuknya Indonesia dalam WTO pada tahun 1995, pemerintah mengeluarkan kebijakan Mei 1995 yang secara umum berisi jadwal penurunan tarif. Penurunan tarif yang dilakukan berbeda dari tahun ke tahun tergantung tingkat tarif yang ada sebelum 1995. Sebagai hasil Pakmei 95, tarif rata-rata Indonesia telah turun dari 20\% di 1994 menjadi kurang dari $8 \%$ di tahun 2000. Sementara, Pemerintah juga menyepakati kerjasama perdagangan di kawasan ASEAN untuk meningkatkan perdagangan antar anggota ASEAN.

\section{II.2 Kebijakan Kerjasama Perdagangan di Kawasan ASEAN}

Kerjasama perdagangan di kawasan ASEAN secara resmi diumumkan pada 24 Februari 1977 yang disebut dengan Preferential Trade Arrangement (PTA) dan dalam perkembangannya menjadi ASEAN Free Trade Area (AFTA). PTA mengusulkan pelaksanaan perdagangan bebas melalui lima cara $^{3}$. Dari kelima cara yang diusulkan tersebut, hanya pengurangan tarif yang dilaksanakan cukup luas bagi barang-barang yang diperdagangkan dan berasal dari negaranegara anggota ASEAN.

AFTA melalui CEPT (Common Effective Preferential Tariff) merupakan wujud dari kesepakatan negara-negara anggota ASEAN untuk membentuk suatu kawasan bebas perdagangan, untuk meningkatkan daya saing ekonomi kawasan regional ASEAN. Pada KTT ke-4 telah diputuskan bahwa AFTA akan dicapai dalam waktu 15 tahun (1 Januari 1993-1 Januari 2008) dan hanya menyangkut produk manufaktur, kemudian dipercepat menjadi tahun 2003, dan terakhir dipercepat lagi menjadi tahun 2002.

Sampai tahun 2002, tarif bea masuk impor yang dikenakan terhadap barang-barang yang diperdagangkan di antara kawasan ASEAN-6 (Brunei Darussalam, Indonesia, Malaysia, Filipina, Singapura, dan Thailand) diturunkan sampai pada tingkat 0-5\%, kecuali untuk produk sensitif, seperti beras, dan produk yang secara tetap dikecualikan, seperti narkotika dan substansi psikotropika. Komitmen Indonesia dibawah skema CEPT-AFTA menunjukkan bahwa pada 2003 sekitar 99,07\% tarif CEPT Indonesia telah berada pada kisaran 0-5\%. Disamping itu, kesepakatan dalam AFTA tidak hanya untuk menurunkan tarif tetapi juga penghapusan hambatan kuantitatif (quantitative restriction) dan hambatan non-tarif (non-tariff barriers).

Pada pertemuan 12 Juli 2003 di Jakarta, disepakati percepatan integrasi terhadap 11 sektor prioritas ASEAN ${ }^{4}$. Selanjutnya untuk masing-masing sektor prioritas tersebut, tarif akan diturunkan hingga nol, hambatan non tarif dihapuskan, dan batasan nilai tukar terhadap produk-

3 Kelima cara tersebut adalah menyetujui pengurangan tarif, kontrak jangka panjang, pendanaan impor dengan syarat-syarat yang lunak, mengutamakan pembelian yang dilakukan oleh pemerintah, dan pembebasan dari hambatan non tariff dalam perdagangan di ASEAN

4 Ke sebelas sektor prioritas ASEAN tersebut meliputi produk kayu, otomotif, produk karet, tekstil, garmen, produk pertanian, produk perikanan, elektronik, produk kesehatan, transportasi udara, dan pariwisata. 
produk tersebut akan diharmonisasikan ${ }^{5}$. Disamping itu, dengan makin keterikatannya dalam dunia global maka Indonesia juga terikat dengan aturan dalam WTO.

\section{II.3 WTO}

Hampir seluruh produk termasuk dalam jadwal komitmen dengan WTO, kecuali barangbarang tertentu seperti kendaraan bermotor, industri baja, pesawat udara, perkapalan, dan barang bersenjata (arms and explosives).

Komitmen dengan WTO untuk barang-barang industri mencakup ${ }^{6}$ antara lain sebagai berikut:

- Menghilangkan tariff surcharge pada tahun 2004. Hal ini telah dilakukan Indonesia pada tahun 1996, jauh sebelum batas waktu yang ditetapkan.

- Menghilangkan seluruh hambatan non-tarif (NTB/non tariff barrier) pada tahun 2004. Indonesia telah meniadakan sebagian besar dari NTB sebelum putaran Uruguay berakhir.

- Menjaga tarif yang berlaku dibawah batas maksimum yang ditetapkan dalam komitmen WTO. Pada kenyataan, sebagian besar tarif produk industri Indonesia berada jauh di bawah tarif maksimum tersebut.

- Mengurangi tarif untuk produk-produk teknologi informasi sampai dengan $0 \%$.

Sesuai dengan jadwal penurunan tarif, sebagian besar tariff line $(83,4 \%)$ sudah berada pada kisaran 0-10\% pada 2003. Bahkan 67,9\% dari total tariff lines telah diturunkan menjadi $0 \%$ atau $5 \%$.

Sementara, krisis nilai tukar yang berlanjut menjadi krisis finansial pada 1997 "membuka" kebijakan perdagangan yang harus sejalan dengan komitmen yang tertuang dalam Lol antara pemerintah Indonesia dengan IMF.

\section{II.4 LOI}

Pada intinya, perjanjian dalam Lol terikat pada pinjaman yang diberikan oleh IMF dan harus sudah dilaksanakan pada saat program IMF berakhir pada Desember 2002. Perlu dicatat, komitmen dalam Lol yang tidak diatur dalam penawaran Indonesia pada Putaran Uruguay sifatnya dapat ditarik kembali setelah program IMF berakhir. Kebijakan perdagangan yang tertuang dalam Lol meliputi? :

5 Hasil kesepatan menteri ekonomi ASEAN di Cambodia, September 2003.

6 Magiera, Stephen L (2003), Readings in Indonesian Trade Policy (1991-2002),p. 36-1 - 36-6

7 Magiera, Stephen L (2003), Readings in Indonesian Trade Policy (1991-2002),p. 36-8 - 36-9 


\section{II.4.1 Tarif}

- Perjanjian dengan IMF sebagian besar telah tercakup dalam Paket Kebijakan Mei 1995 (Pakmei 95). Pemerintah setuju untuk mengurangi tarif menjadi 5\% pada Februari 1998 untuk mengurangi dampak depresisasi rupiah pada harga makanan. Tarif untuk produk pertanian bukan makanan juga turut dikurangi namun secara bertahap, dengan target maksimum 10\% pada 2003.

- Sektor pertanian, industri besi, dan petrokimia termasuk dalam sektor yang mendapat pengecualian dari pengurangan tarif. Selain itu, menurut Pakmei 95 akan ada tiga besaran tarif yakni 0, 5 dan 10\% pada 2003.

- Untuk komoditi beras, ditetapkan tarif sebesar Rp430 per kg sampai Agustus 2000. Sementara untuk komoditi gula, dalam tiga tahun tarif akan diturunkan sebesar $25 \%$.

\section{II.4.2 Hambatan Non-tarif untuk produk industri}

Pemerintah Indonesia setuju untuk menghilangkan NTB sepanjang tidak dapat dijustifikasi dengan masalah keamanan dan lingkungan. Jumlah itemsyang disetujui lebih besar dari skedul dengan WTO.

\section{II.4.3 Hambatan non-tarif untuk produk pertanian}

Pemerintah setuju untuk menghapus monopoli impor yang dimiliki Bulog, kecuali untuk komoditas beras. Penghapusan NTB ini juga lebih luas dari yang dijadwalkan dalam WTO, dimana monopoli yang dimiliki oleh perusahaan milik negara masih diperbolehkan.

\section{II.4.4 Pajak Ekspor dan Hambatan Ekspor lainnya}

Dalam Lol, pemerintah Indonesia setuju untuk menghapus sebagian besar dari hambatan ekspor. Pencabutan hambatan ekspor di antaranya meliputi penghapusan pajak ekspor untuk produksi kulit, bijih besi, dan sisa aluminium serta secara bertahap mengurangi pajak ekspor untuk kayu gelondongan, sawn timber, rotan dan mineral sampai menjadi maksimum 10\%.

Dampak dari kebijakan perdagangan yang harus ditempuh oleh pemerintah karena keterikatan dengan bantuan program IMF tersebut membuat pasar Indonesia termasuk dalam pasar yang paling terbuka, bahkan bila dibandingkan dengan negara maju sekalipun. Dalam beberapa tahun terakhir, arus masuk barang impor, khususnya barang konsumsi meningkat pesat, dan beberapa perusahaan domestik yang tidak dapat bertahan terpaksa mengurangi 
atau menutup usahanya. Pertanyaannya, bagaimana dampak kebijakan liberalisasi perdagangan yang makin terbuka tersebut terhadap tingkat harga industri di pasar domestik?. Dengan makin meningkatnya persaingan apakah akan mengurangi tingkat excess profit perusahaan domestik yang bersifat oligopolistik, sehingga pada akhirnya akan mempengaruhi tingkat harga di pasar domestik? Bab berikutnya akan mendiskusikan model dan analisa dampak kebijakan liberalisasi perdagangan terhadap pembentukan harga barang industri di pasar domestik melalui pendekatan SCP dimana kinerja perusahaan diukur dengan PCM.

\section{PEMBENTUKAN MODEL DAN ANALISA HASIL ESTIMASI}

Studi mengenai ukuran dan kecepatan respon harga domestik terhadap perubahan harga eksternal sangat penting bagi bank sentral untuk membantu dalam pengambilan kebijakan ekonomi moneter dalam rangka pencapaian tingkat inflasi sesuai dengan yang ditargetkan. Misalkan respon harga domestik cepat dan signifikan terhadap perubahan harga eksternal, maka stabilisasi nilai tukar menjadi instrumen yang efektif dalam mengurangi tingkat inflasi pada sektor industri. Sebaliknya jika harga domestik tidak terlalu dipengaruhi oleh harga eksternal, maka kebijakan makroekonomi dalam mengurangi excess demand dan kebijakan mengenai upah menjadi lebih efektif dalam menstabilkan tingkat harga. Besaran dari koefisien harga eksternal tersebut juga merupakan hal yang penting dalam pengambilan kebijakan untuk menghadapi persaingan. Jika hubungan antara kedua harga tersebut kuat, maka perdagangan bebas merupakan alternatif yang memungkinkan untuk meningkatkan daya saing produk domestik.

Kebijakan liberalisasi perdagangan bagi negara berkembang seringkali merupakan komitmen yang harus dilakukan karena bersifat "global" atau dalam suatu "conditionality" sehingga kebijakan liberalisasi perdagangan yang dilakukan oleh suatu negara berkembang kemungkinan tidak diikuti dengan kesiapan sektor usaha domestik. Akibatnya kebijakan liberalisasi dapat menimbulkan dampak yang kurang menguntungkan bagi dunia usaha domestik karena kemungkinan kalah bersaing sebagai akibat masih kurang efisiennya industri dalam negeri. Ketika ekonomi harus dibuka sangat lebar maka hal ini akan berdampak terhadap ekonomi domestik dimana salah satunya tingkat harga domestik. Dengan makin terbukanya suatu ekonomi melalui penurunan atau pembebasan tarif bea masuk maka barang impor akan membanjiri pasar

\footnotetext{
8 Dilihat dari skala usaha, sekitar $70 \%$ dari total perusahaan tersebut berskala sedang.

9 Beberapa industri yang tidak mengalami penurunan jumlah perusahaan pada 1997 adalah tembakau; penerbitan, percetakan dan reproduksi media rekaman; kimia dan barang-barang dari bahan kimia; logam dasar; mesin dan perlengkapannya; serta mesin listrik lainnya dan perlengkapannya.

10 Kenaikan tenaga kerja pada kelompok industri mesin dan perlengkapannya; mesin dan peralatan kantor, akuntansi, dan pengolahan data; serta peralatan kedokteran, alat-alat ukur, peralatan navigasi, peralatan optik, dan jam dimana masing-masing mengalami kenaikan jumlah tenaga kerja yang cukup besar.
} 
domestik. Persaingan antara produsen dalam negeri dengan luar negeri akan makin tajam sehingga sektor/subsektor yang tidak efisien akan keluar dari industri. Selanjutnya dengan meningkatnya impor akan mendorong harga domestik akan menurun dan selanjutnya akan menurunkan tingkat inflasi. Bab ini menyajikan model dampak kebijakan liberalisasi perdagangan terhadap pembentukan harga barang industri melalui pendekatan price-cost margin. Sebelum pembahasan model dan analisa hasil estimasi, kondisi industri di Indonesia akan dianalisa secara umum.

\section{III.1 Sekilas Industri di Indonesia}

Masalah utama dalam menganalisa dampak kebijakan liberalisasi terutama terkait dengan ketersediaan data. Hampir seluruh data (kecuali yang disebutkan) yang digunakan untuk analisa ini merupakan hasil pengolahan dari data hasil survei yang dilakukan oleh BPS.

Dalam kurun waktu 1990-1997 jumlah perusahaan industri berskala besar dan sedang menunjukkan tendensi yang meningkat ${ }^{11}$. Namun demikian sejak krisis finansial pada 1997/ 98, jumlah perusahaan cenderung menurun secara gradual meskipun sudah mulai meningkat pada 2002 (Gambar III.1).

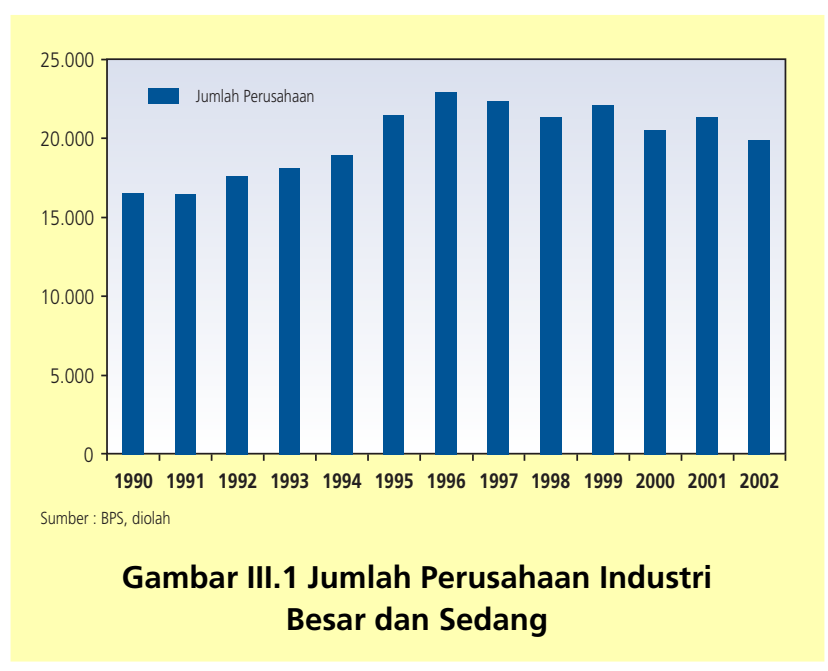

Selama periode krisis 1997/98, jumlah perusahaan mengalami penurunan masing-masing sebesar 3\% dan 4\% pada 1997 dan 1998. Pada periode tersebut, penurunan jumlah perusahaan terjadi hampir di seluruh kelompok industri'12. Pada tahun 2001, secara keseluruhan jumlah

11 Dilihat dari skala usaha, sekitar $70 \%$ dari total perusahaan tersebut berskala sedang.

12 Beberapa industri yang tidak mengalami penurunan jumlah perusahaan pada 1997 adalah tembakau; penerbitan, percetakan dan reproduksi media rekaman; kimia dan barang-barang dari bahan kimia; logam dasar; mesin dan perlengkapannya; serta mesin listrik lainnya dan perlengkapannya. 
perusahaan sudah meningkat terutama terkait dengan pertambahan jumlah perusahaan pada kelompok industri mesin dan perlengkapannya; dan peralatan kedokteran, alat ukur, navigasi, optik, dan jam. Sementara itu dilihat dari komposisi jumlah perusahaan menurut jenis industri, sekitar 50\% jumlah perusahaan terdiri dari kelompok industri makanan dan minuman, pakaian jadi, tekstil, dan furnitur.

Perbandingan jumlah tenaga kerja yang bekerja di sektor industri terhadap total keseluruhan tenaga kerja nasional di seluruh sektor dalam sepuluh tahun terakhir rata-rata di bawah $14 \%$. Bahkan pertumbuhan tenaga kerja pernah negatif pada saat terjadinya krisis akibat banyaknya pemutusan hubungan kerja. Meskipun demikian, sejalan dengan perkembangan jumlah perusahaan, maka tenaga kerja di industri besar dan sedang menunjukkan tendensi kenaikan pada periode 1990-1996. Pertumbuhan tenaga kerja di sektor industri skala besar dan sedang mulai melambat sejak tahun 1997 bahkan menurun pada periode krisis 1997/98.

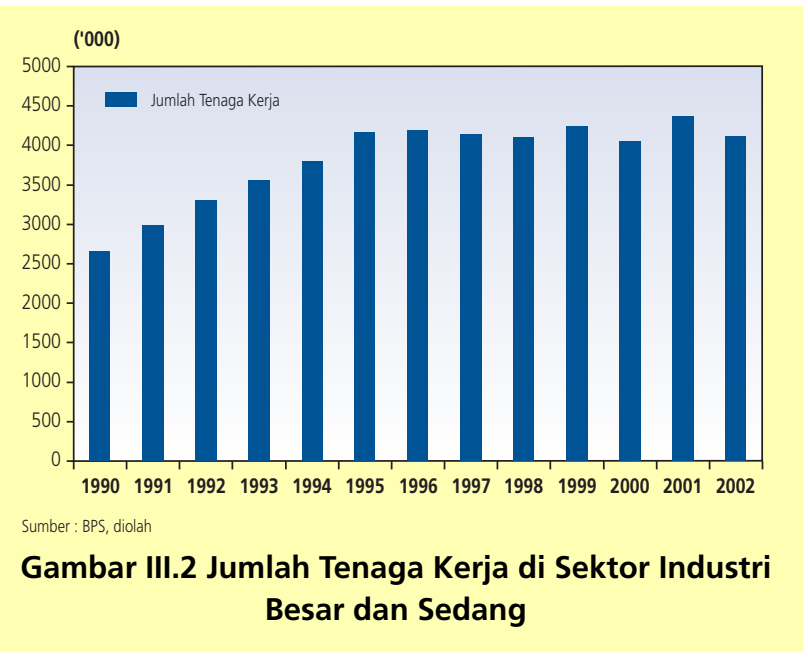

Di lihat dari skala industri, pertumbuhan jumlah tenaga kerja pada tahun 1999 dan 2000 di industri besar dan sedang lebih tinggi dari pertumbuhan tenaga kerja seluruh sektor. Pada tahun 2001 dan tahun 2002 terjadi sebaliknya, tenaga kerja nasional tumbuh 1,08\% dan 0,92\% sedangkan tingkat pertumbuhan tenaga kerja industri besar dan sedang hanya $0.37 \%$ pada tahun 2001 dan menurun 0,41\% pada tahun 2002.

Sementara, struktur pasar industri secara umum menunjukkan struktur pasar yang relatif masih terkonsentrasi. Dengan menggunakan ukuran concentration ratio 4 perusahaan (CR3) untuk mengukur market power, maka CR4 dari 10 kelompok industri masih berkisar antara 
76-96\%. Hal ini mengindikasikan bahwa 4 perusahaan terbesar dapat menguasai pangsa pasar yang sangat besar. Selanjutnya, jika dilihat lebih jauh, maka 37\% dari kelompok industri 5 digit ISIC level mempunyai CR3 yang cukup besar yaitu diatas 75\% (Tabel III.1). Hal ini mengindikasikan bahwa 3 perusahaan terbesar dapat menguasai pasar lebih dari 75\%. Dengan kata lain, masih cukup banyak kelompok industri yang sangat terkonsentrasi.

\begin{tabular}{r|r|l|r|r}
\multicolumn{2}{|c}{ Tabel III.1 Rasio Konsentrasi di atas 75\% } \\
No. & KLUI & \multicolumn{1}{|c}{ Jenis industri } & CR3 & \# Perus \\
\hline 1 & 15321 & tepung terigu & 100,0 & 3 \\
2 & 26411 & semen & 100,0 & 4 \\
3 & 29113 & komponen dan suku cadang motor penggerak mula & 96,3 & 6 \\
4 & 35911 & sepeda motor dan sejenisnya & 95,0 & 12 \\
5 & 24231 & bahan farmasi & 94,6 & 9 \\
6 & 26501 & barang dari marmer dan granit untuk keperluan rumah tangga dan pajangan & 91,8 & 4 \\
7 & 24123 & pupuk buatan majemuk hara makro primer & 91,6 & 7 \\
8 & 24122 & pupuk buatan tunggal hara makro primer & 90,6 & 9 \\
9 & 26111 & kaca lembaran & 90,3 & 12 \\
10 & 28931 & alat pertanian dari logam & 89,3 & 15 \\
11 & 23204 & pembuatan minyak pelumas & 86,1 & 6 \\
12 & 25192 & barang-barang dari karet untuk keperluan industri & 85,8 & 22 \\
13 & 26324 & bahan bangunan dari tanah liat selain batu bata dan genteng & 84,3 & 8 \\
14 & 29114 & penunjang industri motor penggerak mula & 82,1 & 21 \\
15 & 23203 & barang-barang dari hasil kilang minyak bumi & 81,3 & 5 \\
16 & 34100 & kendaraan bermotor roda empat atau lebih & 81,1 & 13 \\
17 & 27101 & besi dan baja dasar (iron and steel making) & 77,8 & 14 \\
18 & 26509 & barang dari marmer, granit dan batu lainnya & 77,7 & 35 \\
19 & 24299 & bahan kimia dan barang kimia lainnya & 76,4 & 27 \\
20 & 27320 & pengecoran logam bukan besi dan baja & 75,2 & 7 \\
& & &
\end{tabular}

Meskipun demikian, cukup banyak juga kelompok industri yang pasarnya sudah lebih mendekati persaingan sempurna. Hal ini diindikasikan dengan CR4 yang cukup rendah (sekitar $12 \%)$ pada industri pakaian jadi, barang dari kayu, dan benang.

\section{III.2 Survei Model}

Hanya sedikit studi empiris mengenai dampak kebijakan liberalisasi perdagangan terhadap harga domestik. Yang dan Hwang (2001) mengkaji dampak liberalisasi perdagangan terhadap harga barang industri domestik Korea. Mereka mengacu pada model yang dikembangkan Pugel (1980), yaitu model penentuan harga pada sebuah perusahaan monopoli yang 
menghadapi persaingan dari suatu produk impor. Aplikasi model menggunakan data panel 18 sektor industri dengan 3 digit SIC level untuk periode sampel 1983-1995.

Misalkan $Q_{D}$ dan $Q_{M}$ masing-masing merupakan fungsi permintaan terhadap produk domestik dan impor.

Keduanya adalah fungsi dari kedua harga produk, $P_{D}$ dan $P_{M}$

$$
\begin{aligned}
& Q_{D}=Q_{D}\left(P_{D}, P_{M}\right), Q_{D D}<0, Q_{D M}>0 \\
& Q_{M}=Q_{M}\left(P_{D}, P_{M}\right), Q_{M D}>0, Q_{M M}<0
\end{aligned}
$$

Harga barang impor merupakan fungsi dari pasokan impor,

$$
P_{M}=P_{M}\left(Q_{M}\right), P_{M M}>0
$$

Selanjutnya diasumsikan bahwa sejumlah proporsi tetap dari pendapatan total konsumen $(\gamma)$ dibelanjakan untuk membeli kedua jenis barang tersebut, yakni

$$
P_{D} Q_{D}+P_{M} Q_{M}=\gamma
$$

Perusahaan monopolis tersebut memaksimalkan keuntungan, $Z$, berdasarkan $P_{D}$ dengan kendala fungsi persamaan (III.1) s.d (III.4),

$$
Z=\left(\gamma-P_{M} Q_{M}\right)-C_{D} Q_{D}
$$

dimana $C_{D}=$ biaya marjinal konstan produksi domestik. Kondisi turunan pertama untuk memperoleh keuntungan maksimum adalah:

$$
-Q_{M} \frac{\partial P_{M}}{\partial P_{D}}-P_{M}\left(Q_{M D}+Q_{M M} \frac{\partial P_{M}}{\partial P_{D}}\right)-C_{D}\left(Q_{D D}+Q_{D M} \frac{\partial P_{M}}{\partial P_{D}}\right)=0
$$

dengan menata persamaan (III.6) dan mensubstitusi dengan rasio penetrasi impor, m,dimana,

$$
m=\frac{P_{M} Q_{M}}{P_{D} Q_{D}+P_{M} Q_{M}}
$$

maka harga domestik adalah

$$
P_{D}=C_{D} \phi\left(\frac{1-m}{m}\right)
$$

dimana

$$
\phi=\left(\frac{\varepsilon_{D D} \varepsilon_{M M}-\varepsilon_{D M} \varepsilon_{M D}}{\varepsilon_{M S}}-\varepsilon_{D D}\right) /\left(\frac{\varepsilon_{M D}}{\varepsilon_{M S}}+\varepsilon_{M D}\right)
$$




$$
\begin{aligned}
\varepsilon_{M S}= & \text { elastisitas harga barang impor } \\
\varepsilon_{D D}= & \text { elastisitas harga barang domestik terhadap } \\
& \text { permintaan barang domestik } \\
\varepsilon_{M M}= & \text { elastisitas harga barang impor terhadap permintaan } \\
& \text { barang impor } \\
\varepsilon_{M D}, \varepsilon_{D M}= & \text { elastisitas permintaan barang domestik terhadap } \\
& \text { permintaan barang impor dan sebaliknya. }
\end{aligned}
$$

Implikasi utama dari persamaan (III.8) adalah bahwa efek kompetisi impor terhadap harga barang domestik tergantung pada pangsa impor, $m$. Karena $\varepsilon_{D D} \varepsilon_{M M}-\varepsilon_{D M} \varepsilon_{M D}=0$ maka harga barang domestik yang ditentukan oleh pelaku monopoli akan turun jika pangsa impor meningkat, yaitu $\frac{\partial P_{D}}{\partial m}<0$.

Dengan melakukan modifikasi terhadap model dimana PCM tergantung pada tingkat kompetisi industri tersebut dan pangsa impor, persamaan (III.8) menjadi :

$$
P_{D}=\frac{C_{D}}{1-\left[1-\left(\frac{m}{1-m}\right)\left(\frac{1}{\phi}\right)\right] S}, 0 \leq S \leq 1
$$

dimana $S$ adalah tingkat kompetisi, $0 \leq S \leq 1$.S=0 jika industri berada dalam kompetisi sempurna $(P C M=0)$. $S=1$ jika industri bersifat monopolistik murni.

Dengan melinierisasi persamaan (III.10), dan mensubstitusinya dengan variabel-variabel yang dapat diukur, diperoleh persamaan empiris harga domestik berikut:

$$
P_{i t}=\beta_{0}+\beta_{1} U L C_{i t}+\beta_{2} U M C_{i t}+\beta_{3} M D_{i t}+\beta_{4} C R_{i t}+\beta_{5} I P R_{i t}
$$

dimana $\mathrm{P}_{\text {it }}$ merupakan harga domestik industri i pada periode $t$; ULC dan UMC mewakili biaya tenaga kerja dan biaya bahan baku per unit output. MD dan CR masing-masing merupakan variabel permintaan pasar dan rasio konsentrasi pasar; dan IPR adalah rasio penetrasi impor.

Pada persamaan (III.11) tingkat kompetisi impor tidak mempengaruhi struktur market, sementara berdasarkan Pugel (1980), efek dari kompetisi impor diharapkan lebih kuat di industri domestik yang terkonsentrasi. Karena pada persamaan (III.11) belum dimodifikasi dengan memasukkan unsur interaksi antara $C R$ dan IPR maka interaksi keduanya perlu dikaji untuk menganalisa dampak dari kompetisi impor terhadap industri domestik yang lebih terkonsentrasi. Di samping itu penambahan interaksi variabel juga diperlukan untuk $M D$ dan $C R$ untuk merefleksikan kemungkinan bahwa efek dari perubahan permintaan pasar lebih besar jika 
industri kurang kompetitif, dengan suatu biaya produksi tertentu. Dengan demikian persamaan (III.11) menjadi:

$$
\begin{aligned}
& P_{i t}=\beta_{0}+\beta_{1} U L C_{i t}+\beta_{2} U M C_{i t}+\beta_{3} M D_{i t}+\beta_{4} C R_{i t} \\
& +\beta_{5} I P R_{i t}+\beta_{6} C R \cdot I P R+\beta_{7} C R \cdot M D
\end{aligned}
$$

dengan hipotesis berikut: $\beta_{0}, \beta_{1}, \beta_{2}, \beta_{3}, \beta_{4}, \beta_{7}>0 ; \quad \beta_{5}, \beta_{6}<0$

Dengan menggunakan persamaan (III.12), Yang dan Hwang (2001) menemukan bahwa kenaikan rasio penetrasi impor sebesar 10\%, akan menurunkan harga domestik kira-kira $3 \%-4 \%$. Besarnya efek dari kompetisi impor ini tergantung pada struktur pasar industrinya. Secara umum dapat dikatakan bahwa besarnya efek tersebut akan lebih kuat di industri yang lebih terkonsentrasi.

Pendekatan lain dalam menganalisis dampak kebijakan liberalisasi terhadap perilaku pembentukan harga adalah dengan indikator PCM, yang mengukur pengaruh indikator liberalisasi perdagangan terhadap perilaku perusahaan yang tercermin dari kinerja marjin keuntungannya. Pendekatan yang lebih spesifik adalah dengan langsung terfokus pada pengujian import-discipline hypothesis. Pendekatan ini menghipotesiskan bahwa peningkatan pangsa impor akibat adanya kebijakan liberalisasi perdagangan akan menghilangkan excess profit dari perusahaan domestik yang bersifat oligopolistik, sehingga perusahaan tersebut menjadi lebih kompetitif. Hal ini didasarkan atas argumen bahwa dengan makin terbukanya pasar maka akan meningkatkan persaingan sehingga akan menghilangkan sifat oligopolistik dalam suatu perekonomian. Akibatnya keuntungan yang dinikmati oleh oligopolis akan berkurang sehingga mereka akhirnya "hanya" akan menikmati "normal profit" dimana harga akan sama (atau mendekati) biaya marjinal. Akibat selanjutnya perusahaan yang sebelumnya tidak efisien, tetapi bisa bertahan karena adanya proteksi yang bersifat regulasi, kemungkinan menjadi tidak dapat bertahan lagi sehingga hanya sektor yang efisien yang akan terus bertahan.

Salah satu studi yang menggunakan PCM dilakukan oleh Yalcin (2000) yang memfokuskan pada pengujian import-discipline hypothesis dengan memasukkan variabel rasio penetrasi impor pada model SCP standar dengan spesifikasi umum:

$P C M=f(C, E, X, B)$

dimana PCM merupakan fungsi dari variabel-variabel yang mencerminkan tingkat kompetisi pada industri (C), elastisitas permintaan industri (E), keterbatasan input $(\mathbf{X})$, dan barrier to entry (B). Vektor $\mathrm{C}$ umumnya terdiri dari variabel rasio konsentrasi pasar, rasio penetrasi impor, dan pangsa ekspor. $\mathbf{X}$ adalah vektor variabel yang mencerminkan perbedaan di antara industri yang 
terkait dengan ketersediaan input industri, misalnya tenaga kerja yang ahli atau produktif, modal kerja, dan bahan baku impor. Sementara itu B adalah vektor variabel-variabel yang mempengaruhi barrier to entry, seperti rasio iklan terhadap penjualan dan rasio pengeluaran riset dan pengembangan terhadap penjualan.

Hubungan negatif antara PCM dengan pangsa impor dapat dijelaskan dari persamaan (III.6) model Pugel (1980), dimana

$$
\frac{\partial P_{M}}{\partial P_{D}}=\frac{P_{M M} Q_{M D}}{1-P_{M M} Q_{M M}}
$$

Melalui penataan dan penyederhanaan persamaan (III.6) dan (III.14), diperoleh PCM yang memaksimalkan keuntungan,

$$
P C M=\frac{P_{D}-C_{D}}{P_{D}}=\frac{P_{M} Q_{M}}{P_{D} Q_{D}}\left[\left(\frac{\varepsilon_{M D}}{\varepsilon_{M S}}+\varepsilon_{M D}\right) /\left(\varepsilon_{D D}-\left(\varepsilon_{D D} \varepsilon_{M M}-\varepsilon_{D M} \varepsilon_{M D}\right) / \varepsilon_{M S}\right)\right]+1
$$

Jadi PCM optimal suatu perusahaan monopolistik merupakan fungsi dari pangsa impor $\left(P_{M} Q_{M}\right.$ $\left.P_{D} Q_{D}\right)$ dan berbagai elastisitas penawaran dan permintaan. Berdasarkan restriksi persamaan (III.4) diperoleh magnitud elastisitas $\varepsilon_{D D} \varepsilon_{M M}-\varepsilon_{D M} \varepsilon_{M D}=0$, sehingga bagian persamaan pada kurung siku di persamaan (III.15) menjadi negatif. Dengan demikian, PCM dan pangsa impor memiliki hubungan negatif,

$$
\frac{d\left(\frac{P_{D}-C_{D}}{P_{D}}\right)}{d\left(\frac{P_{M} Q_{M}}{P_{D} Q_{D}}\right)}<0
$$

\section{III.3 Penerapan Model}

Dalam penelitian ini pengaruh liberalisasi perdagangan internasional dan struktur pasar terhadap kinerja pasar domestik diuji dengan pendekatan SCP. Hipotesis yang akan diuji adalah bahwa perdagangan internasional yang semakin liberal telah mendorong perusahaanperusahaan industri domestik memperbaiki kinerjanya dengan menjaga kestabilan atau mengurangi marjin keuntungan (PCM) agar menjadi lebih kompetitif. Ukuran liberalisasi perdagangan diwakili oleh variabel keterbukaan perdagangan internasional (opennes) dan rasio penetrasi impor. Pada pengujian indikator opennes, dampak pada peningkatan daya saing terjadi pada industri yang menjual produknya baik ke pasar domestik maupun pasar internasional 
(barang ekspor). Jika keterbukaan didominasi oleh impor, maka excess profit akan berkurang, sehingga keuntungan yang dinikmati hanyalah berupa "normal profit". Sedangkan jika tingkat keterbukaan didominasi oleh ekspor, maka stock domestik akan mengalami shortage karena arus produksi domestik mengalir ke luar negeri. Hal ini tentu saja akan meningkatkan harga barang di pasar domestik, yang pada akhirnya justru meningkatkan harga domestik, sehingga keuntungan akan bertambah. Sementara itu penggunaan indikator rasio penetrasi impor merupakan pengujian berlaku tidaknya import-discipline hypothesis di Indonesia.

\section{III.3.1 Struktur model}

Studi ini mengadaptasi model yang digunakan oleh Yang dan Hwang (2001) dan Yalcin (2000) dengan beberapa modifikasi. Model tersebut pada dasarnya hampir sama, karenanya dapat dijadikan saling melengkapi.

Setelah mempertimbangkan ketersediaan data untuk alternatif variabel, alternatif struktur model analisis panel data yang digunakan adalah sebagai berikut:
1: $\mathrm{PCM}_{i t}=\alpha_{i}+\beta_{1} C R_{i t}+\beta_{2} U L C_{i t}+\beta_{3} U M C_{i t}+\beta_{4} O_{i t}$
2: $\mathrm{PCM}_{i t}=\alpha_{i}+\beta_{2} U L C_{i t}+\beta_{3} U M C_{i t}+\beta_{5} C R^{\star} O_{i t}$
3: $P C M_{i}=\alpha_{i}+\beta_{1} C R_{i t}+\beta_{2} U L C_{i t}+\beta_{3} U M C_{i t}+\beta_{4} I P R_{i t}$
4: $P C M_{i t}=\alpha_{i}+\beta_{2} U L C_{i t}+\beta_{3} U M C_{i t}+\beta_{5} C R^{\star} I P R_{i t}$

Variabel PCM $_{i t}$ menandakan PCM industri i pada tahun $t$; PCM merupakan selisih antara harga dengan biaya marginal. PCM dihitung dari nilai tambah dikurangi biaya tenaga kerja dibagi output ${ }^{13}$ sebagai berikut:

$$
P C M=\frac{p-M C}{p} \approx \frac{(Q-I C)-L C}{Q}=\frac{V A-L C}{Q}
$$

dimana VA adalah nilai tambah bersih, Q merupakan nilai output, IC adalah biaya antara (seluruh biaya di luar biaya tenaga kerja, depresiasi dan pajak tidak langsung), dan LC merupakan biaya tenaga kerja. Penggunaan variabel harga barang di pasar domestik $\left(P_{i t}\right)$ sebagai variabel endogen tidak dimungkinkan karena tidak tersedianya data harga domestik untuk setiap barang industri (indeks harga produsen) KLUI 3 digit.

Variabel $O$ dan IPR masing-masing merupakan rasio tingkat keterbukaan perdagangan internasional dan rasio penetrasi impor. Kedua variabel tersebut merupakan indikator liberalisasi secara tidak langsung, karena pada dasarnya sulit untuk mengukur tingkat liberalisasi suatu 
sektor industri secara langsung. Tingkat keterbukaan dari setiap sektor $(\mathrm{O})$ diukur dengan impor (M) ditambah ekspor (X), kemudian dibagi dengan output sektoral, sedangkan IPR merupakan pangsa impor terhadap total penjualan di pasar domestik.

$$
O=\frac{(X+M)}{Q}
$$

$C R$ adalah tingkat konsentrasi pasar 4 perusahaan dengan produksi terbesar. Indikator ini merupakan ukuran kompetisi domestik dan seringkali digunakan sebagai salah satu ukuran penguasaan pasar (market power). Dalam pendekatan SCP, indikator CR digunakan untuk menganalisa bahwa sektor yang makin terkonsentrasi akan meningkatkan PCM.

Selanjutnya, CRO dan CRIPR merupakan interaksi antara indikator liberalisasi perdagangan dengan struktur pasar industri, yang dimaksudkan untuk melihat efek kompetisi impor terhadap PCM pada industri yang lebih terkonsentrasi. Dua variabel lainnya, ULC dan UMC masing-masing merupakan rasio biaya tenaga kerja dan biaya bahan baku per nilai output;

Paremeter $\alpha$ merupakan intercept dan $\beta$ adalah parameter variabel penjelas, dengan hipotesa $\beta_{1}>0$ dan $\beta_{2}, \beta_{3}, \beta_{5}<0$, sedangkan $\beta_{4}$ bisa bernilai positif, bisa juga bernilai negatif, tergantung apakah ekspor atau impor yang mendominasi pasar domestik. Parameter $\beta_{1}$ diharapkan positif karena dengan rasio konsentrasi yang semakin besar tingkat kompetisi domestik berkurang. Kondisi itu diduga memperbesar kekuatan pasar suatu perusahan sehingga dapat menetapkan harga di atas biaya marjinal. Sebaliknya parameter $\beta_{2}$, dan $\beta_{3}$ diperkirakan negatif karena peningkatan efisiensi dapat memberikan kontribusi pada penurunan biaya yang pada gilirannya memberi ruang bagi kenaikan marjin keuntungan.

Hipotesis nilai negatif untuk $\beta_{4}$ menandakan bahwa perdagangan internasional yang semakin terbuka atau semakin besarnya perbandingan barang impor terhadap total output sektoral, dapat memaksa produsen mengorbankan sebagian marjin keuntungannya untuk bertahan menghadapi persaingan dari kompetitor asing. Sedangkan hipotesa nilai positif untuk $\beta_{4}$ menandakan bahwa produsen lebih memilih untuk mengekpor barangnya ke luar negeri, sehingga barang di pasar domestik menjadi langka. Akibatnya, harga pun menjadi naik, sehingga marjin keuntungan produsen bertambah. Selanjutnya parameter $\beta_{5}$ dihipotesiskan bertanda negatif, untuk variabel $C R^{*} \mid P R$, dan dapat bertanda positif atau negatif untuk variabel $C R^{*} \mathrm{O}$. Pada kedua indikator tersebut, dan $\beta_{5}$ dihipotesiskan lebih signifikan dari $\beta_{4}$ dan bertanda sama. Hal itu menggambarkan hipotesis bahwa pengaruh kompetisi barang impor terhadap perilaku penetapan harga dan marjin keuntungan terjadi lebih kuat pada industri-industri yang lebih terkonsentrasi. 
Pengujian hipotesis mengunakan analisis data panel (pooled time series, cross-section data). Analisis regresi panel data yang diterapkan adalah regresi tertimbang lintas kelompok (cross-section weighted regression) dengan dua option yaitu fixed effect intercept estimator $\left(\alpha_{i}\right)$ dan common intercept estimator $\left(\alpha_{i}=\alpha\right.$ untuk setiap $\left.i=1,2, \ldots, N\right)$.

\section{III.3.2 Data}

Model menggunakan data cross-section 21 kelompok industri besar dan sedang ${ }^{14} \mathrm{KLUI}$ level tiga digit periode 1990-2002 (13 tahun). Data PCM, rasio konsentrasi pasar, biaya tenaga kerja per output, dan biaya material per output dihitung dari data statistik industri besar dan sedang KLUI 3 digit yang diperoleh dari Badan Pusat Statistik. Sementara itu tingkat keterbukaan perdagangan dan rasio penetrasi impor dihitung berdasarkan data statistik industri BPS dan data ekspor impor KLUI 3 digit dari Pusat Data dan Informasi Departemen Perindustrian \& Departemen Perdagangan.

\section{III.4 Hasil Estimasi}

Hasil uji F pada keempat model menunjukkan bahwa perbedaan sum squared residual antara common dan fixed effect siginifikan secara statistik sehingga model yang digunakan adalah model fixed effect. Hasil estimasi ke empat persamaan adalah seperti ditampilkan pada tabel III.2. s.d III.5., masing-masing untuk periode penuh 1990-2002, sub periode pra krisis 1990-1996, dan sub periode 1997-2002.

Pada ketiga periode sampel, estimasi koefisien variabel efisiensi input sangat signifikan secara statistik dan menunjukkan tanda yang sesuai dengan hipotesa. Hal yang menarik terlihat pada kekuatan relatif antara indikator efisiensi tenaga kerja dengan efisiensi material dalam mempengaruhi PCM. Meskipun proporsi biaya tenaga kerja lebih kecil dibandingkan proporsi biaya material dalam struktur biaya (tabel III.2), peningkatan PCM industri pengolahan tampaknya lebih sensitif terhadap perbaikan efisiensi tenaga kerja daripada terhadap peningkatan efisiensi material.

Periode 1990-2002

Untuk hipotesis yang terkait dengan indikator opennes, model 1 pada Tabel III.2 tidak menolak hipotesis hubungan pengaruh positif opennes dengan terhadap PCM (t-stat 3,44). Rasio konsentrasi pasar juga memiliki hubungan searah dengan PCM namun dengan tingkat signifikansi yang lebih rendah (t-stat 1,45). Hubungan positif tersebut diperkuat oleh model 2 yang menggunakan variabel $C R^{\star} O$ dengan signifikansi statistik yang lebih besar (t-stat 4,11 ).

14Penggunaan data 21 kelompok industri KLUI 3 digit setelah memperhitungkan kualitas dan kelengkapan seri datanya. 


\begin{tabular}{|c|c|c|c|c|}
\hline \multicolumn{5}{|c|}{$\begin{array}{l}\text { Tabel III.2 Estimasi Parameter Metode Cross Section Weighte } \\
\text { Fixed Effect Intercept; Periode 1990-2002 }\end{array}$} \\
\hline & (1) & (2) & (3) & (4) \\
\hline$C R$ & $\begin{array}{l}0.054 \\
(1.45)\end{array}$ & $\begin{array}{l}0.039 \\
(0.98)\end{array}$ & & \\
\hline ULC & $\begin{array}{r}-1.244^{* * *} \\
(-6.20)\end{array}$ & $\begin{array}{r}-1.167 * * * \\
(-6.32)\end{array}$ & $\begin{array}{r}-1.108 * * * \\
(-5.26)\end{array}$ & $\begin{array}{r}-1.152 * * * \\
(-5.82)\end{array}$ \\
\hline UMC & $\begin{array}{r}-0.739 * * * \\
(-14.88)\end{array}$ & $\begin{array}{r}-0.749 * * * \\
(-15.16)\end{array}$ & $\begin{array}{r}-0.723^{* * *} \\
(-13.89)\end{array}$ & $\begin{array}{r}-0.731 * * * \\
(-14.16)\end{array}$ \\
\hline 0 & $\begin{array}{r}0.055^{* * *} \\
(3.44)\end{array}$ & & & \\
\hline$C R^{\star} \mathrm{O}$ & & $\begin{array}{r}0.118 * * * \\
(4.11)\end{array}$ & & \\
\hline IPR & & & $\begin{array}{l}0.011 \\
(0.40)\end{array}$ & \\
\hline$C R * I P R$ & & & & $\begin{array}{l}0.047 \\
(1.06)\end{array}$ \\
\hline Adj R2 & 0.906 & 0.907 & 0.873 & 0.882 \\
\hline F-stat & 110.412 & 117.451 & 78.976 & 89.690 \\
\hline DW-stat & 1.808 & 1.764 & 1.640 & 1.656 \\
\hline
\end{tabular}

Sementara itu untuk hipotesis dengan indikator IPR, model 3 dan 4 justru mengindikasikan hubungan yang tidak sesuai hipotesis antara IPR dengan PCM. Estimasi parameter $b_{4}$ dan $b_{5}$ bertanda positif meskipun tidak signifikan secara statistik. Demikian juga terdapat hubungan yang positif tetapi tidak signifikan secara statistik antara rasio konsentrasi pasar dengan PCM.

\section{Periode 1990-1996}

Seperti halnya hasil untuk keseluruhan sampel, pada periode pra krisis indikator opennes berpengaruh positif terhadap PCM. Namun hubungan tersebut tidak signifikan secara statistik (model 1 dan 2). Rasio konsentrasi pasar juga memiliki hubungan searah dengan PCM namun tidak signifikan secara statistik.

Kesamaan hubungan arah dengan hasil estimasi keseluruhan sampel juga terjadi pada hipotesis dengan indikator IPR dimana estimasi parameter $\mathrm{b}_{4}$ bertanda positif bahkan signifikan secara statistik pada 5\% (Tabel III.3 model 3). Hubungan positif pada model 3 tersebut sejalan dengan model 4 yang menghasilkan variabel estimasi parameter $b_{5}$ bertanda positif walaupun dengan tingkat signifikansi yang lebih kecil (t-stat 1,54). 


\begin{tabular}{|c|c|c|c|c|}
\hline & (1) & (2) & (3) & (4) \\
\hline$C R$ & $\begin{array}{l}0.025 \\
(0.88)\end{array}$ & & $\begin{array}{l}0.020 \\
(0.66)\end{array}$ & \\
\hline ULC & $\begin{array}{r}-1.191 * * * \\
(-7.97)\end{array}$ & $\begin{array}{r}-1.195^{* * *} \\
(-8.69)\end{array}$ & $\begin{array}{r}-1.289 * * * \\
(-8.16)\end{array}$ & $\begin{array}{r}-1.192 * * * \\
(-7.54)\end{array}$ \\
\hline UMC & $\begin{array}{r}-0.949 * * * \\
(-24.36)\end{array}$ & $\begin{array}{r}-0.949 * * * \\
(-24.20)\end{array}$ & $\begin{array}{r}-0.965^{* * *} \\
(-23.38)\end{array}$ & $\begin{array}{r}-0.978 * * * \\
(-14.16)\end{array}$ \\
\hline 0 & $\begin{array}{l}0.011 \\
(0.91)\end{array}$ & & & \\
\hline$C R^{\star} \mathrm{O}$ & & $\begin{array}{l}0.005 \\
(0.15)\end{array}$ & & \\
\hline IPR & & & $\begin{array}{r}0.073 * * \\
(1.96)\end{array}$ & \\
\hline$C R^{*} \mid P R$ & & & & $\begin{array}{l}0.112 \\
(1.54)\end{array}$ \\
\hline Adj R2 & 0.991 & 0.989 & 0.989 & 0.984 \\
\hline F-stat & 695.430 & 557.073 & 530.487 & 382.948 \\
\hline DW-stat & 1.845 & 1.893 & 1.842 & 1.852 \\
\hline
\end{tabular}

Periode 1997-2002

Pada periode krisis hubungan opennes dan rasio konsentrasi pasar dengan PCM masingmasing bertanda positif namun tidak signifikan secara statistik (Tabel III.4 model 1). Namun hubungan positif tersebut menjadi signifikan jika menggunakan variabel interaksi keterbukaan perdagangan dengan rasio konsentrasi, $C R * O$ (Tabel III.4 model 2).

Sementara itu pada model 3 hubungan antara IPR dan PCM $\left(\mathrm{b}_{4}\right)$ bertanda negatif dan signifikan secara statistik (t-stat 2,20). Namun hubungan negatif tersebut terjadi karena IPR pada periode krisis secara rata-rata menurun, sedangkan PCM meningkat ${ }^{15}$. Perilaku ini kebalikan dari hipotesis yang diuji yaitu IPR yang meningkat akan menurunkan PCM.

15 Statistik IPR yang menurun pasca krisis mengindikasikan penurunan porsi barang impor dalam konsumsi domestik 


\begin{tabular}{|c|c|c|c|c|}
\hline & (1) & (2) & (3) & (4) \\
\hline$C R$ & $\begin{array}{l}0.057 \\
(0.77)\end{array}$ & & $\begin{array}{l}0.011 \\
(0.16)\end{array}$ & \\
\hline ULC & $\begin{array}{r}-0.819 * * * \\
(-3.16)\end{array}$ & $\begin{array}{r}-0.945^{* * *} \\
(-4.26)\end{array}$ & $\begin{array}{r}-0.723^{* * *} \\
(-2.83)\end{array}$ & $\begin{array}{r}-0.778 * * * \\
(-3.12)\end{array}$ \\
\hline UMC & $\begin{array}{r}-0.430 * * * \\
(-4.82)\end{array}$ & $\begin{array}{r}-0.474^{* * *} \\
(-5.44)\end{array}$ & $\begin{array}{r}-0.389 * * * \\
(-4.44)\end{array}$ & $\begin{array}{r}-0.412 * * * \\
(-4.38)\end{array}$ \\
\hline 0 & $\begin{array}{l}0.015 \\
(0.55)\end{array}$ & & & \\
\hline$C R^{*} \mathrm{O}$ & & $\begin{array}{r}0.105^{* * *} \\
(2.45)\end{array}$ & & \\
\hline IPR & & & $\begin{array}{r}-0.078 * * \\
(-2.20)\end{array}$ & \\
\hline$C R^{*} \mid P R$ & & & & $\begin{array}{l}-0.027 \\
(-0.36)\end{array}$ \\
\hline Adj R2 & 0.951 & 0.955 & 0.955 & 0.962 \\
\hline F-stat & 101.949 & 116.855 & 112.666 & 137.892 \\
\hline DW-stat & 1.865 & 1.904 & 1.711 & 1.761 \\
\hline
\end{tabular}

\section{III.5 Analisis Hasil Estimasi}

Meningkatnya kompetisi yang dihadapi perusahaan industri domestik pada pasar domestik dan global, tampaknya telah menurunkan inflasi harga produk manufaktur. Indikasi tersebut dapat diproksi dari inflasi harga barang manufaktur, baik produk domestik maupun eks impor, pada tingkat perdagangan besar ${ }^{16}$. Perkembangan data indeks harga perdagangan besar manufaktur dari 1986 hingga 2002 menunjukkan tren inflasi yang menurun sejalan dengan meningkatnya impor yang antara lain dipicu oleh kebijakan liberalisasi perdagangan. Namun tekanan kompetisi global dengan meningkatnya liberalisasi perdagangan, ternyata belum sampai memaksa industri domestik mengorbankan sebagian marjin keuntungannya agar tetap bertahan dalam industri tersebut. Bahkan semakin terkonsentrasi suatu industri, semakin besar dan signifikan pengaruh meningkatnya kompetisi impor terhadap kenaikan marjin keuntungan.

16 Data indeks harga produsen manufaktur pada level agregat dan rincian kelompok industri, belum tersedia. 


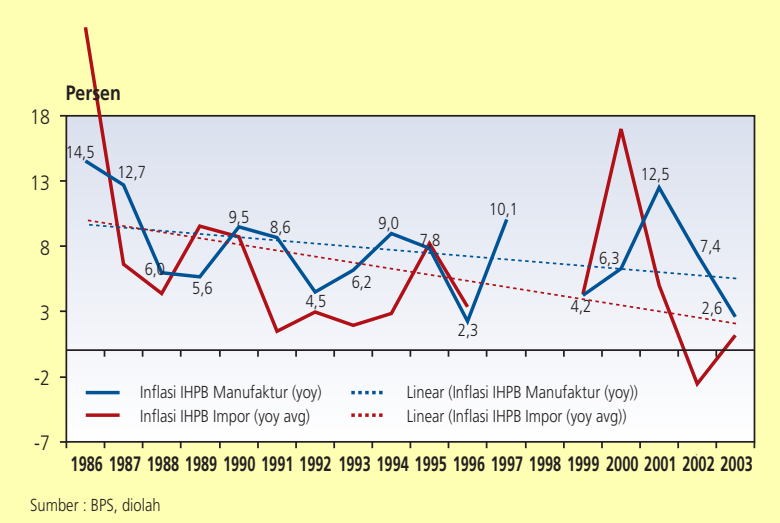

Gambar III.3 Inflasi Indeks Harga Perdagangan Besar Manufaktur dan Impor

\section{III.5.1 Hubungan positif openness terhadap PCM}

Untuk indikator liberalisasi perdagangan yang diukur dengan tingkat keterbukaan, hipotesis nilai negatif untuk $b_{4}$ dan $b_{5}$ tidak didukung oleh model. Hal itu menandakan bahwa perbandingan impor yang semakin besar terhadap produksi, sebagai akibat dari perdagangan internasional yang semakin terbuka, tidak terbukti mendorong penurunan marjin keuntungan.

Sebaliknya, pengujian model mengindikasikan bahwa liberalisasi perdagangan yang meningkat mendorong produsen meningkatkan ekspor. Kondisi ini dapat dijelaskan dari faktor biaya. Tren depresiasi Rupiah menurunkan biaya produksi dalam mata uang asing. Kondisi ini mendorong peningkatan daya saing dan marjin keuntungan industri yang

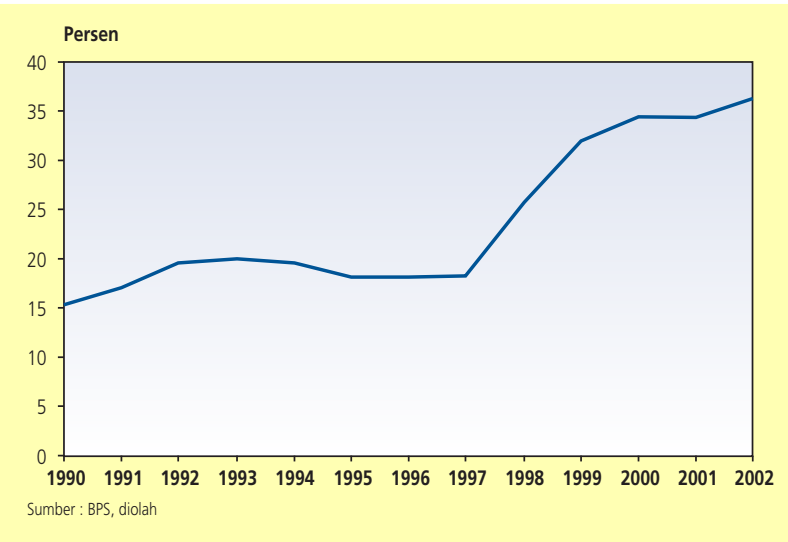

Gambar III.4 Rata-Rata Persentase Ekspor terhadap Output 21 kelompok industri menurut KBLI 3 digit, 1990-2002 
bertujuan ekspor. Peningkatan ekspor juga dapat mempengaruhi kondisi pasokan dan harga domestik, sehingga menaikkan marjin keuntungan dari penjualan domestik.

Gambar III.4 menunjukkan adanya tren peningkatan porsi ekspor terhadap output industri domestik terutama pada periode krisis. Kondisi ini menggambarkan peningkatan penetrasi ekspor output industri domestik. Hal tersebut dapat menjelaskan mengapa estimasi parameter $\mathrm{b}_{5}$ signifikan secara statistik pada periode krisis tetapi tidak signifikan pada pra krisis.

Oleh karena itu pengaruh positif tingkat liberalisasi yang diukur dengan tingkat keterbukaan terhadap PCM kemungkinan karena faktor peningkatan liberalisasi secara umum lebih terkait dengan peningkatan ekspor daripada impor. Secara rata-rata selama periode penelitian (19902002) kenaikan ekspor lebih tinggi dari kenaikan impor (Gambar III.5 dan III.6). Sehingga secara

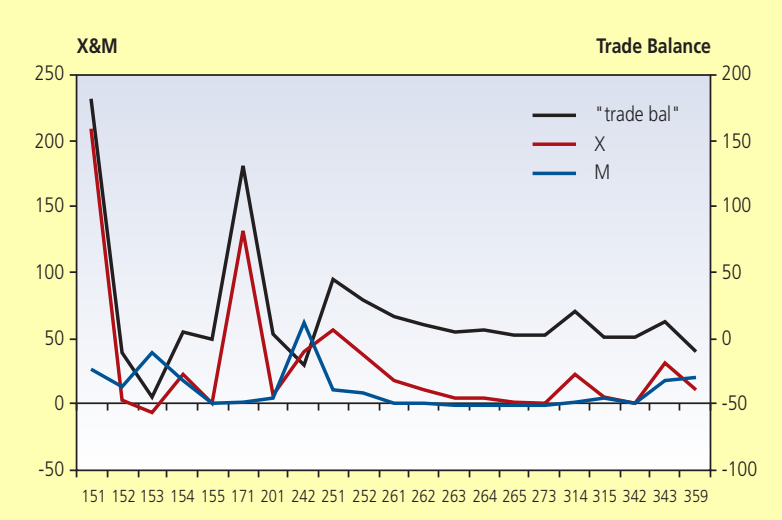

Gambar III.5 Rata-rata Perubahan Ekspor dan Impor, 1990-2002 (juta US\$)

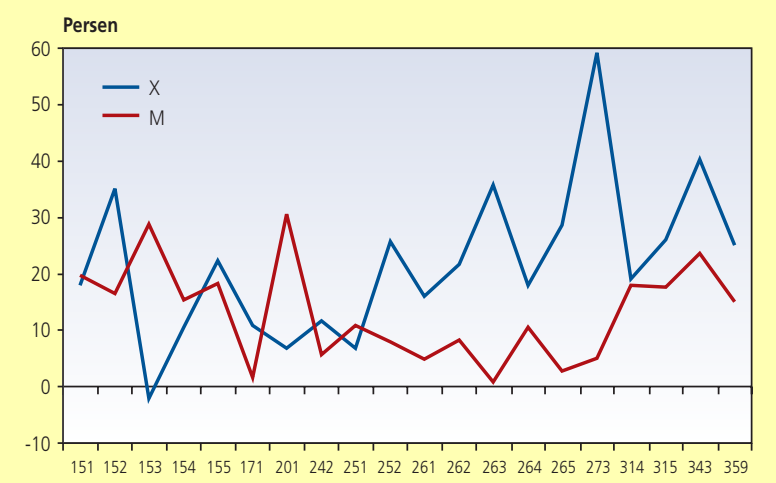

Gambar III.6 Rata-rata Pertumbuhan Ekspor dan Impor, 1990-2002 
rata-rata menyumbang positive balance of trade untuk banyak kelompok industri selama periode tersebut.

Peningkatan ekspor yang lebih tinggi dari impor terutama terjadi setelah krisis nilai tukar 1997/98. Sedangkan impor secara rata-rata tidak banyak menunjukkan peningkatan pada sebagian besar kelompok industri (Gambar III.7). Sebaliknya, sebelum periode krisis nilai tukar, peningkatan impor relatif sebanding dengan peningkatan ekspor untuk banyak kelompok industri bahkan untuk beberapa kelompok industri terjadi negative trade balance yang cukup besar (Gambar III.8).

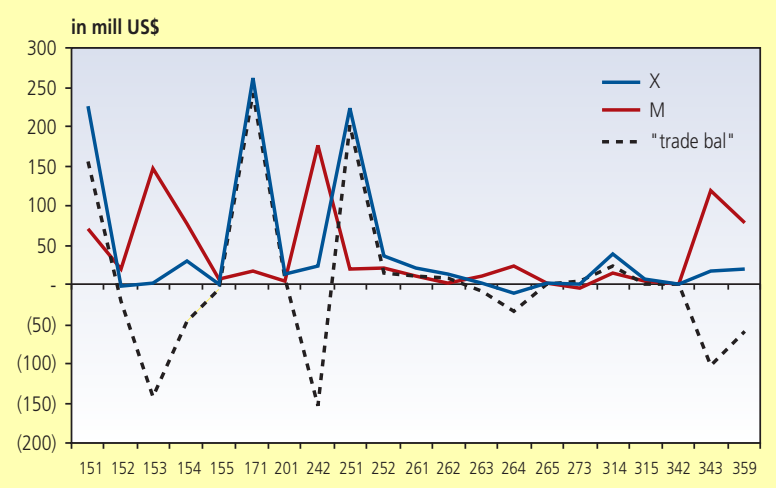

Gambar III.7 Rata-rata Perubahan Ekspor dan Impor, 1990-1996

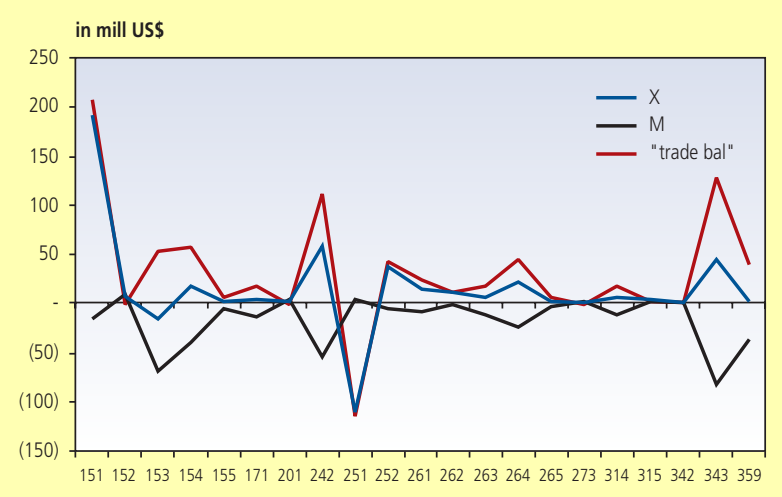

Gambar III.8 Rata-rata Perubahan Ekspor dan Impor, 1997-2002 


\section{III.5.2 Hubungan pengaruh positif IPR terhadap PCM}

Untuk indikator liberalisasi perdagangan yang diukur dengan IPR, hasil pengujian juga tidak mendukung hipotesis nilai negatif untuk $b_{4}$ dan $b_{5}$. Hal itu menandakan bahwa semakin besar pangsa barang impor terhadap total barang yang dijual di pasar domestik, justru semakin besar marjin keuntungan produsen industri domestik secara rata-rata.

Peningkatan efisiensi dan produktivitas tampaknya menjadi salah satu faktor yang dapat mempertahankan daya saing industri tanpa harus mengorbankan marjin keuntungan. Hasil regresi memperlihatkan kuatnya pengaruh perbaikan efisiensi biaya material lokal dan impor dan efisiensi biaya tenaga kerja terhadap kenaikan PCM. Peningkatan efisiensi biaya bahan baku impor dipengaruhi oleh beberapa faktor. Pertama, penurunan inflasi harga bahan baku impor yang diindikasikan oleh menurunnya tren inflasi harga perdagangan besar barang impor, yang di dalamnya mencakup bahan baku dan penolong (Gambar III.3). Kedua, kandungan impor produk industri yang masih tinggi seperti diindikasikan dari persentasi biaya bahan baku impor terhadap biaya bahan baku total yang masih di atas 30\% meski trennya menurun (Gambarlll.9).

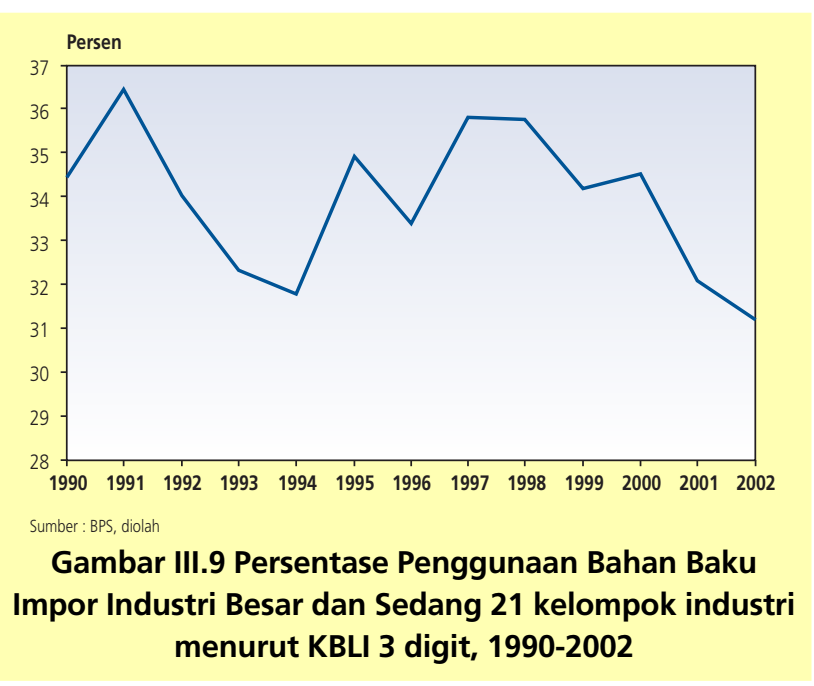

Selanjutnya peningkatan efisiensi biaya tenaga kerja sejalan dengan meningkatnya produktivitas tenaga kerja pada industri pengolahan yang diukur dari nilai tambah riil per pekerja. Meskipun sempat mengalami penurunan pasca krisis, produktivitas pekerja manufaktur kembali meningkat menjadi Rp9,4 juta per tenaga kerja pada 2002, namun masih di bawah produktivitas rata-rata 1997 sebesar Rp9,6 juta per tenaga kerja (Gambar III.10). Kenaikan produktivitas tersebut kemungkinan didorong oleh peningkatan efisiensi penggunaan jumlah tenaga kerja pada pasca krisis sehingga tenaga kerja yang diserap cenderung memiliki kualifikasi yang lebih 
baik daripada kondisi sebelum krisis. Meski pengaruhnya siginifikan secara statistik tetapi kontribusinya terhadap peningkatan marjin keuntungan sangat kecil sehingga tidak dimasukkan dalam model yang ditampilkan.

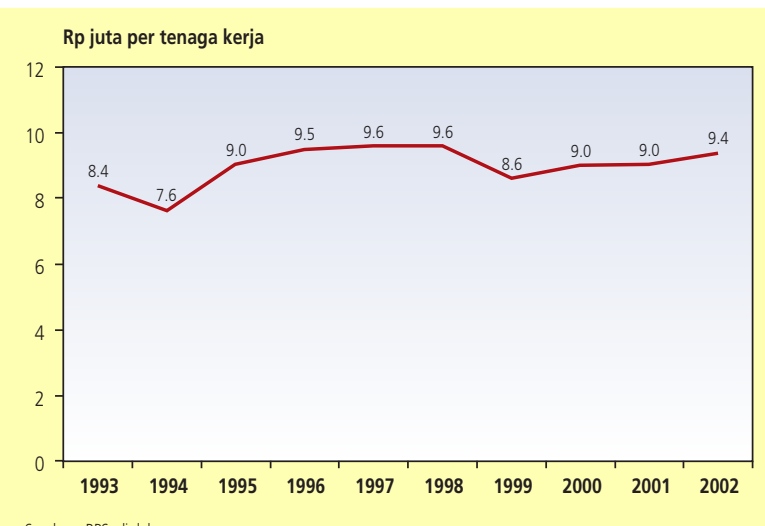

Sumber: BPS, diolah

Gambar III.10 Produktivitas Tenaga Kerja Industri

Pengolahan, 1993-2002

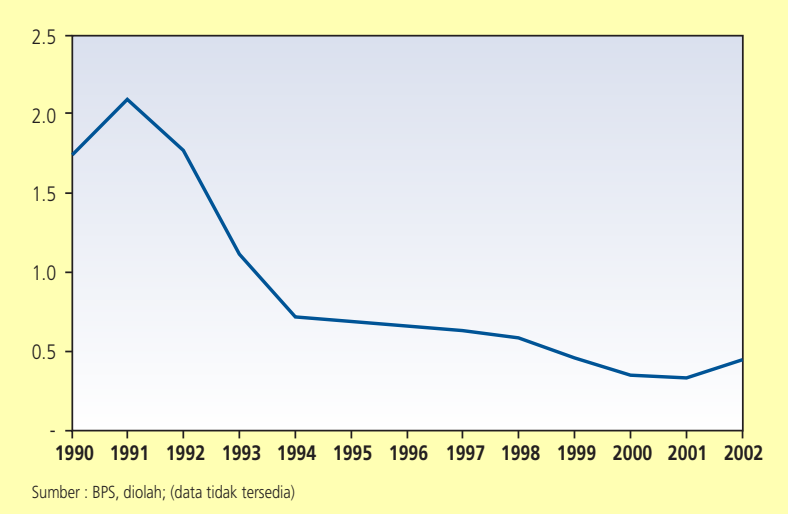

Gambar III.11 Rasio Modal terhadap Output (COR) 21 kelompok industri menurut KBLI 3 digit, 1990-2002

Faktor penunjang lain di sisi efisiensi adalah meningkatnya efisiensi penggunaan modal dalam menghasilkan output. Indikator tersebut ditunjukkan oleh rasio modal terhadap output (COR) yang menurun (Gambar III.11). Peningkatan efisiensi ini selain dipicu oleh peningkatan produktivitas pada lantai produksi juga terkait dengan meningkatnya depresiasi barang modal yang diterapkan dalam perhitungan nilai buku barang modal pada akhir periode. Variabel depresiasi tidak dikeluarkan dalam perhitungan PCM karena data 1996, 2001, dan 2002 tidak 
tersedia di samping pada sejumlah kelompok menghasilkan PCM negatif. Namun untuk data panel lainnya, PCM yang telah mengeluarkan depresiasi masih menunjukkan tren yang meningkat.

Selain faktor efisiensi, ditolaknya hipotesis pengaruh kenaikan CR*IPR dalam menurunkan PCM, dapat dijelaskan oleh tiga kemungkinan yang memerlukan penelitian lebih lanjut. Pertama, kemungkinan adanya hubungan yang bersifat simultan (simultaneity bias) antara PCM dengan rasio konsentrasi atau dengan variabel impor sebagai komponen pembentuk rasio keterbukaan perdagangan. Dalam hal ini hubungan rasio konsentrasi pasar dengan marjin keuntungan tidak sepenuhnya didasarkan pada hipotesis kekuatan pasar yang mengacu pada perilaku perusahaan yang oligopolistik. Jalur transmisi lain adalah hubungan sebab akibat dari marjin keuntungan ke konsentrasi pasar. Kekuatan skala ekonomi produksi dapat meningkatkan daya efisiensi perusahaan, yang selanjutnya mempengaruhi perilaku pembentukan harga untuk memperbesar keuntungan. Selanjutnya laba ditahan digunakan untuk melakukan ekspansi usaha sehingga pada akhirnya rasio konsentrasi semakin besar (Clarke, 1984). Demikian pula dapat terjadi hubungan kausalitas dari marjin keuntungan mempengaruhi impor. Dalam hal ini tingkat harga dan kenaikan marjin keuntungan industri oligopolistik domestik, yang dipicu oleh skala usaha dan daya efisiensi yang besar, mendorong produsen luar negeri untuk memasarkan produknya ke pasar domestik.

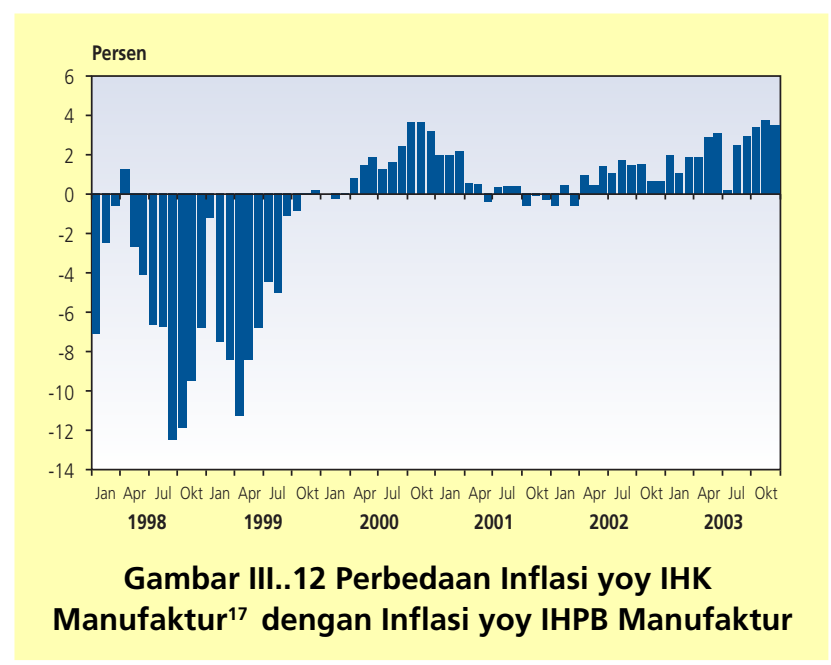

Kemungkinan kedua, meningkatnya impor dapat mendorong terjadinya kolusi implisit antara produsen domestik dan asing dalam pasar yang sangat terkonsentrasi, di mana derajat

17 Inflasi IHK Manufaktur dihitung dengan mengeluarkan item jasa dan barang-barang konsumen yang bukan merupakan hasil industri pengoalahan. 
perilaku kolusif tersebut lebih kuat dibandingkan derajat kolusi implisit antara sesama perusahaan domestik. Bentuk kerjasama misalnya dapat terjadi antara produsen domestik dengan perusahaan importir (agen perusahaan produsen luar negeri) yang berada dalam satu kelompok perusahaan yang sama. Untuk produk yang sama, kedua perusahaan tersebut dapat lebih mudah berkoordinasi dalam memisahkan segmentasi pasar antara produk lokal dan impor sehingga memungkinkan untuk meraih marjin keuntungan yang meningkat. Kemungkinan ketiga adalah terjadinya merger atau akuisisi dalam bentuk pembelian sebagian saham perusahaan domestik oleh perusahaan asing sehingga keduanya dapat berkoordinasi dalam menetapkan strategi kebijakan output dan harga.

Selain faktor-faktor yang terkait dengan struktur industri dan keterbukaan perdagangan luar negeri, kenaikan marjin keuntungan dapat juga dipengaruhi oleh perbedaan inflasi di tingkat produsen, perdagangan besar dan perdagangan eceran. Gambar 3.12 menunjukkan lebih besarnya inflasi barang manufaktur di tingkat ritel dibandingkan inflasi barang manufaktur di tingkat grosir pada periode setelah krisis $^{18}$. Bahkan perbedaan tersebut semakin besar sejak periode 2002-2003. Lebih jauh, data tersebut memberikan indikasi marjin keuntungan yang cenderung meningkat pada pedagang retail barang manufaktur. Hal tersebut dapat mengurangi insentif bagi perusahaan industri untuk menurunkan harga atau memperlambat laju kenaikan harga di tingkat produsen.

\section{KESIMPULAN DAN IMPLIKASI KEBIJAKAN}

Kebijakan liberalisasi perdagangan yang ditempuh Indonesia melalui kerangka WTO, AFTA, maupun IMF conditionality telah meningkatkan keterbukaan Indonesia terhadap perdagangan internasional. Keterbukaan tersebut secara umum berdampak pada tren meningkatnya porsi barang impor dalam pasokan total barang di pasar domestik dan porsi ekspor terhadap output industri.

Meskipun keterbukaan perdagangan internasional berdampak positif terhadap penurunan biaya input industri dan penetrasi di pasar global, namun belum mendorong perilaku pembentukan harga industri yang wajar. Perilaku tersebut diindikasikan oleh peningkatan marjin keuntungan sehingga kurang meningkatkan kesejahteraan masyarakat (public welfare) sementara di lain pihak, produsen semakin diuntungkan. Perilaku pembentukan harga tersebut menandakan adanya fenomena kekakuan penurunan marjin keuntungan (downward profitmargin rigidity) yang menyebabkan inflasi menjadi persisten.

18 Pada periode krisis (1998-1999), inflasi IHK Manufaktur lebih rendah dibandingkan inflasi IHPB Manufaktur. Hal itu dapat dipengaruhi oleh faktor daya beli konsumen yang merosot sehingga memaksa pedagang eceran mengerem kenaikan harga dengan mengurangi marjin keuntungannya. 
Peningkatan efisiensi biaya produksi, interaksi dan hubungan kausalitas dua arah antara marjin keuntungan dengan konsentrasi pasar dan dengan kompetisi impor, serta peningkatan porsi output yang diekspor, merupakan faktor-faktor yang dapat menjelaskan fenomena tersebut. Lebih jauh temuan tersebut membawa indikasi bahwa secara umum pelaku industri yang mampu bertahan di pasar, cukup kompetitif menghadapi meningkatnya persaingan pasar.

Karakteristik hubungan positif antara marjin keuntungan dan interaksi konsentrasiketerbukaan perdagangan membawa implikasi dua pilihan kebijakan industri, yaitu mendorong merger atau dekonsentrasi industri. Merger meningkatkan konsentrasi pasar sehingga di satu sisi dapat mengarah pada kebijakan tingkat harga dan marjin keuntungan yang meningkat, namun di sisi lain dapat menurunkan biaya melalui faktor skala ekonomi. Kondisi itu dapat menimbulkan rijiditas penurunan marjin keuntungan (downward profit-margin rigidity).

Sebaliknya kebijakan pengurangan konsentrasi industri mendorong perilaku penetapan harga dan keuntungan yang tidak berlebihan, sementara perusahaan didorong untuk melakukan efisiensi biaya karena adanya tekanan kompetisi yang meningkat. Jika pasar kurang terkonsentrasi, tidak terdapat cukup banyak perusahaan besar yang dapat menetapkan harga produk industri di pasar. Akibatnya peningkatan efisiensi akan mendorong penurunan PCM karena pasar domestik yang bertambah kompetitif. Pada gilirannya hal ini akan memperlambat laju kenaikan harga atau bahkan mendorong penurunan harga. Kebijakan ini relatif lebih memberikan peningkatan kesejahteraan masyarakat.

Persistensi inflasi yang bersumber dari kenaikan marjin keuntungan industri pengolahan sebenarnya menunjukkan adanya potensi penurunan inflasi IHK ke depan. Potensi tersebut cukup besar karena barang industri pengolahan memiliki bobot yang besar, yaitu sekitar $70 \%$, dalam keranjang IHK. Prospek penurunan inflasi itu antara lain tergantung pada efektivitas kebijakan yang mendukung dekonsentrasi industri dan kebijakan yang menyangkut deregulasi struktur dan rantai perdagangan barang manufaktur. Potensi penurunan inflasi dari efektivitas kebijakan industri dan perdagangan menjadi masukan bagi penentuan sasaran inflasi jangka menegah-panjang yang ditetapkan pemerintah

Perilaku pembentukan harga yang mendorong persistensi inflasi merupakan tantangan bagi Bank Indonesia dalam usahanya mencapai sasaran inflasi jangka menengah-panjang. Oleh karena itu upaya mempercepat peningkatan kredibilitas sasaran inflasi perlu menjadi perhatian. Upaya tersebut antara lain dengan memperjelas sinyal arah dan konsistensi kebijakan moneter untuk pencapaian sasaran inflasi serta terus meningkatkan koordinasi kebijakan dengan pemerintah.

19 Price-cost margin biasa dihitung sebagai penjualan dikurangi biaya tenaga kerja dan bahan baku, kemudian dibagi dengan penjualan 20 Penggunaan data 21 kelompok industri KLUI 3 digit setelah memperhitungkan kualitas dan kelengkapan seri datanya. 


\section{DAFTAR PUSTAKA}

Astiyah, Siti; Clarita L. Iskandar, Rendra Z. Idris, Tri Yanuarti. (2004). Profil Sektor Perdagangan. Program Kerja Reguler Bagian Studi Sektor Riil, Direktorat Riset Ekonomi dan Kebijakan Moneter Bank Indonesia.

Carlton, Dennis W \& Jeffrey M. Perloff (2000). Modern Industrial Organization. Addison - Wesley.

Caves, Richard E.(1980). Industrial Trade and Industrial Organization: Introduction. Journal of Industrial Economics. Vol. 29, No. 2. (Dec. 1980), pp. 113-117.

Clarke, Roger; Stephen Davies, Michael Waterson (1984). The Profitability-Concentration Relation: Market Power or Efficiency?. Journal of Industrial Economics, Vol.32, No.4 (Jun. 1984), pp. 435-450.

Domowitz, lan; R. Glenn Hubbard, Bruce C. Petersen (1986). The Intertemporal Stability of the Concentration-Margins Relationship. Journal of Industrial Economics, Vol.35, No.1 (Sep. 1986), pp. 13-34.

Erdem, Erkan \& James R. Tybout (2003). Trade Policy and Industrial Sector Responses: Using Evolutionary Models to Interpret the Evidence, Paper presented at the May 2003 Brooking Trade Forum Conference in Washington D.C.

Evans, William N., Luke M. Froeb, Gregory J. Werden (1993). Endogeneity in the Concentration-Price Relationship: Causes, Consequences, and Cures. Journal of Industrial Economics, Vol.41, No.4 (Dec. 1993), pp. 431-438.

Feridhanusetyawan, Tubagus \& Mari Pangestu (2002). Indonesian Trade Liberalization: Estimating The Gains, Centre for Strategic and International Studies (CSIS), Jakarta.

Holtermann, Sally (1973). Market Structure and Economic Performance in U.K. Manufacturing. Journal of Industrial Economics, Vol.22, No.2 (Jun. 1973), pp. 119-139.

Jayanthakumaran, K. (2002). The Impact of Trade Liberalisation on Manufacturing Sector Performance in Developing Countries: A Survey of the Literature, University of Wollongong Department of Economics Working Paper WP02-07.

Magiera, Stephen L. (2003). Readings in Indonesian Trade Policy (1991-2002). Collection of Papers. 
Metin-Ozcan, Kivilcim; Ebru Voyvoda, Erinc Yeldan (2000). On The Patterns Of Trade Liberalization, Oligopolistic Concentration and Profitability: Reflections from Post-1980 Turkish Manufacturing. Bilkent University.

Kim, Chuk Kyo (2003). Industrial Development Strategy for Indonesia: Lessons from Korean Experience. UNSFIR Discussion Paper Series No.03/02.

Pugel, Thomas A. (1980). Foreign Trade and US Market Performance. Journal of Industrial Economics, Vol. 29, No.2 (Dec. 1980), pp.119-29.

Prabowo, Dibyo, Sonia Wardoyo [2004]. AFTA Suatu Pengantar. Edisi 2004/2005. BPFEYOGYAKARTA. Yogyakarta.

Topalova, Petia (2004). Trade Liberalization and Firm Productivity: The Case of India. IMF Working Paper WP/04/28

Yalcin, Cihan (2000). Price-Cost Margins and Trade Liberalization in Turkish Manufacturing Industry: A Panel Data Analysis. Central Bank of Turkey.

Yang, Yung Y. \& Min Hwang (2001). Effects on Trade Liberalization

21 Inflasi IHK Manufaktur dihitung dengan mengeluarkan item jasa dan barang-barang konsumen yang bukan merupakan hasil industri pengoalahan.

22 Pada periode krisis (1998-1999), inflasi IHK Manufaktur lebih rendah dibandingkan inflasi IHPB Manufaktur. Hal itu dapat dipengaruhi oleh faktor daya beli konsumen yang merosot sehingga memaksa pedagang eceran mengerem kenaikan harga dengan mengurangi marjin keuntungannya. 
halaman ini sengaja dikosongkan 